\title{
Influence of Heat Treatment on the Corrosion Resistance of Aluminum-Copper Coating
}

\author{
Mieczyslaw Scendo ${ }^{1, *(1)}$, Slawomir Spadlo ${ }^{2}$, Katarzyna Staszewska-Samson ${ }^{1}$ \\ and Piotr Mlynarczyk ${ }^{2}$ \\ 1 Institute of Chemistry, Jan Kochanowski University in Kielce, Uniwersytecka 15G, PL-25406 Kielce, Poland; \\ katarzyna.staszewska@onet.pl \\ 2 Department of Computer Techniques and Armaments, Kielce University of Technology, Tysiaclecia Panstwa \\ Polskiego 7, PL-25314 Kielce, Poland; sspadl@tu.kielce.pl or sspadlo@onet.pl (S.S.); \\ piotrm@tu.kielce.pl (P.M.) \\ * Correspondence: scendo@ujk.edu.pl; Tel.: +41-349-7045; Fax: +41-349-7062
}

Received: 8 June 2020; Accepted: 14 July 2020; Published: 17 July 2020

\begin{abstract}
Influence of heat treatment on the corrosion resistance of the aluminum-copper (Al-Cu) coating on the aluminum substrate was investigated. The coating was produced by the electrical discharge alloying (EDA) method. The surface and microstructure of the specimens were observed by a scanning electron microscope (SEM). The phase analysis of the composite materials by X-ray diffraction (XRD) and energy-dispersive spectroscopy (EDS) indicated that intermetallic compounds (i.e., $\mathrm{CuAl}_{2}$ and $\mathrm{Cu}_{9} \mathrm{Al}_{4}$ ) were formed through reactions between $\mathrm{Al}$ and $\mathrm{Cu}$. during the EDA process. A significant increase in the hardness of the $\mathrm{Al}-\mathrm{Cu}$ coating was affected by the improvement of the alloy structure. The heat treatment of materials was carried out at $400{ }^{\circ} \mathrm{C}$ or $600{ }^{\circ} \mathrm{C}$ in the air atmosphere. A corrosion test of materials was carried out by using electrochemical methods. The corrosive environment was acidic chloride solution. After heat treatment at $400{ }^{\circ} \mathrm{C}$ the mechanical properties of the $\mathrm{Al} / \mathrm{Cu}$ alloy increased significantly and the oxide layer protect of the alloy surface against corrosion. However, after heat treatment at elevated temperature, i.e., $600{ }^{\circ} \mathrm{C}$ it was found that the $\left(\mathrm{Al}_{2} \mathrm{O}_{3}\right)_{\text {ads }}$ and $(\mathrm{CuO})_{\text {ads }}$ coatings were destroyed. The mechanical properties of the $\mathrm{Al} / \mathrm{Cu}$ alloy decreased, and its surface has undergone deep electrochemical corrosion.
\end{abstract}

Keywords: electrical discharge alloying; copper coating; heat treatment; acidic chloride solution; corrosion parameters; corrosion rate

\section{Introduction}

Electrical discharge alloying (EDA) is a new surface alloying method that uses a composite electrode as an alloying material to improve the surface chemical and mechanical properties of structural materials. The EDA method is carried out using short-lived, high-current electrical pulses with a very low total heat input [1,2]. The EDA method achieves a metallurgical bonded coating on a metal substrate. The short duration of the electric impulse allows for extremely fast solidification of the deposited material and the formation of a fine-grained, homogeneous coating with an almost amorphous structure. The obtained EDA method coating has exceptionally good tribological and anticorrosion properties $[3,4]$. However, during the EDA process the release of capacitor energy will generate a high temperature plasma arc between the electrode tip and the substrate. The electrode material is ionized by the plasma arc and the molten electrode material is transferred onto the substrate. The scheme of the electrical discharge alloying coating deposition on a metal substrate is shown in Figure 1. Moreover, additional information on the mathematical model of the EDA process can be found in article [5]. 


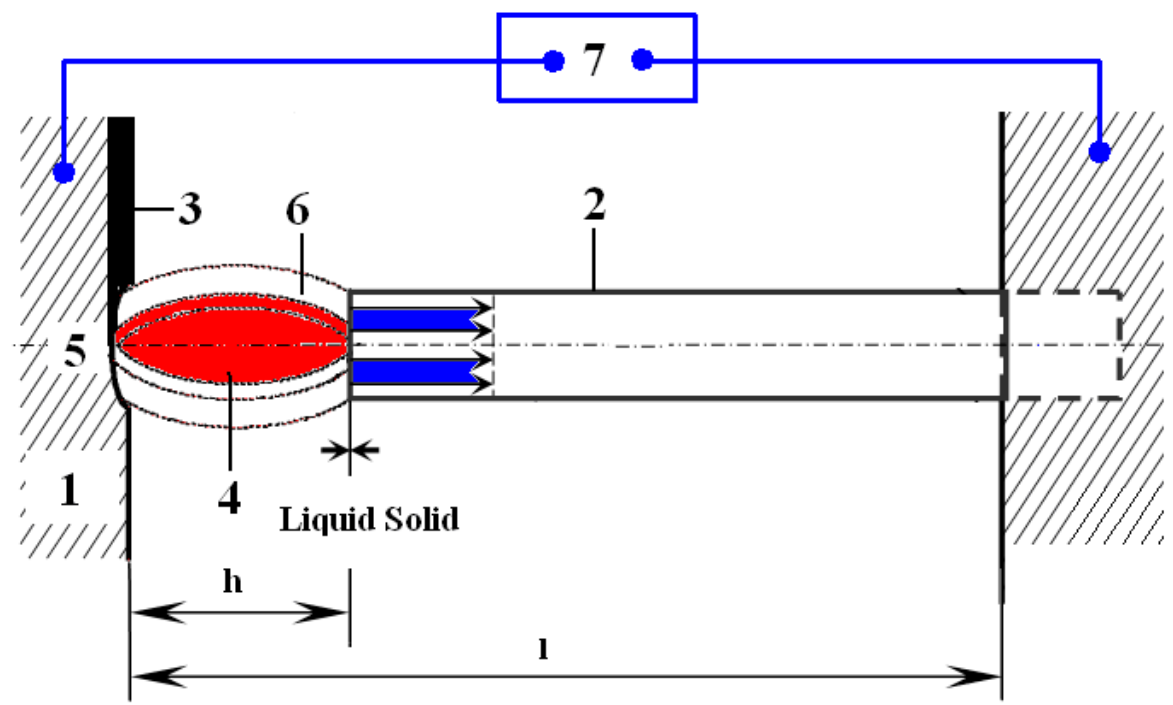

Figure 1. Scheme the electrical discharge alloying coating deposition: 1—substrate (cathode), 2-erode as coating material (anode), 3-coating, 4-plasma, 5-diffusion/reaction zone, 6-protective gas, 7-power generator, $\mathrm{h}$ - height plasma and $\mathrm{l}$-length erode.

In the initial stage of deposition, physical and chemical processes take place in the inter-electrode gap (called the frontal) and the substrate. The EDA technology relies on the phenomenon of electrical discharge, which is accompanied by mass transport and energy dissipation. As a result of erosion of the working electrode (erode) the electrode particles deposit on a metal substrate (cathode). Moreover, the deposition of the coating takes place with the simultaneous heating of the substrate at the contact point of both electrodes. In this area, local melting of the electrodes occurs, so-called electrical discharge. Furthermore, the electrical discharge process is associated with the ionization and heating of the air to a high temperature of up to ten thousand degrees. However, the phase composition and properties of the deposited coatings depend on the type of substrate material and the electrode. The generated composite coating shows improved hardness and protects the substrate against wear. It is the result of interactions between the material of the erode and the metallic substrate. It is worth mentioning that in some cases discharge coatings are more roughened than the substrate. Moreover, the tensile stresses may be created on the coated surface, which significantly reduce the fatigue strength of the materials. Undesirable effects of the EDA coating can be minimized or eliminated by mechanical or laser treatment [3-5].

Low-density aluminum has a relatively lower hardness than other metals. Therefore, metals such as: $\mathrm{Fe}, \mathrm{Mg}$, Mo or Ti were used to improve the mechanical properties of aluminum [6-9]. Moreover, various methods have been used to obtain a good quality coating of various metals on the $\mathrm{Al}$ surface. In addition, good adhesion of the tested metals to the aluminum surface was obtained. To increase the hardness of $\mathrm{Al}$, its surface was covered with more hard composites, e.g., carbon nanotubes (CNT) [10]. It was found that the increase in the mechanical characteristics of Al was attributed to the effects of the particular strengthening by CNT and the regularly oriented carbon nanotubes achieved through the nanoscale dispersion method. Recently, interest in aluminum and copper composites was increasing, as these composites combine the lightweight properties of $\mathrm{Al}$ and the thermal characteristics of $\mathrm{Cu}$. The accumulative roll bonding (ARB) is one of the latest methods used to produce of the $\mathrm{Al} / \mathrm{Cu}$ composite material [11]. It turned out that the $\mathrm{ARB}$ method can achieve a copper coating on a metal substrate in this case the average thickness of $\mathrm{Cu}$ layer decreased from 100 to $7 \mu \mathrm{m}$. It is worth noting that the strength and hardness of the copper coating clearly increased. However, the authors of the work [12] in order to obtain the Al-Cu/DLC (diamond like carbon) composite applied the squeeze casting (SC) method. It was reported that the thermal conductivity of the investigated composite increased significantly. Moreover, the aluminum/copper composite 
materials were successfully fabricated by the spark plasma sintering (SPS) method [13]. It was found that of the $\mathrm{Al} / \mathrm{Cu}$ mechanical properties have improved considerably as well as the copper content affects physical properties of the $\mathrm{Al} / \mathrm{Cu}$ composite material. Moreover, an increase in the amount of intermetallic compounds was found in the composite material.

Recently, research on the deformation behavior and precipitation features of $\mathrm{Al} / \mathrm{Cu}$ alloys were carried out. Among others, the authors of the work [14] researched of high temperature compressive features of the Al/Cu alloy. They showed that a high temperature significantly reduces the effect of compressive features of the alloy. Liu et al. [15] described the continuous dynamic recrystallization behavior of a compressed $\mathrm{Al} / \mathrm{Cu}$ alloy at the temperature range of $350-500{ }^{\circ} \mathrm{C}$. Whereas the authors of the work [16] discussed the effect of a cooling rate and solution time on the precipitated transformation of $\mathrm{Al} / \mathrm{Cu}$ alloy, and they found that the precipitation of the new phases was enhanced with increased cooling rate and solution time. Moreover, deformation behavior and precipitation features of the $\mathrm{Al} / \mathrm{Cu}$ alloy were investigated using uniaxial tensile tests at intermediate temperatures [17]. It was found that the true stress drops with the decreased strain rate or the increased deformation temperature.

The properties of the copper/aluminum $(\mathrm{Cu} / \mathrm{Al})$ clad and copper/aluminum/copper $(\mathrm{Cu} / \mathrm{Al} / \mathrm{Cu})$ laminated composites have been studied by [18-20]. Both composites were fabricated by the cold rolling method (CR) [21,22]. Their advantages associated with high conductivity, low density and good surface performance. Therefore, the $\mathrm{Cu} / \mathrm{Al}$ and $\mathrm{Cu} / \mathrm{Al} / \mathrm{Cu}$ composites have been successfully utilized in the fields of electrical and electronic components [23,24].

Accordingly, many efforts have recently been made to develop surface modification or the production of new surface materials whose properties differ from those of the substrate. The most efficient and recommended for the production of metallic protective coatings is the electrical discharge alloying method, because: (i) it is possible to produce thin (i.e., number $\mu \mathrm{m}$ ) or thick (i.e., number $\mathrm{mm}$ ) metallic coatings, (ii) metallic coatings are characterized by good adhesion with the substrate and (iii) metallic coatings can be applied in strictly defined places and on complicated shapes. Moreover, in some cases the EDA coatings are rough. In addition, tensile stresses can be created on the surface of the coating, which significantly reduce the fatigue strength of the materials.

Aluminum is very useful in fabricating lightweight structures. However, the tribological applications of these materials are limited. This paper presents a brief study on improving the mechanical properties and corrosion resistance of aluminum by covering the surface with a copper layer using the electrical discharge alloying method. However, there is no information in the literature regarding the anticorrosive properties of the Al-Cu coatings that were produced by the EDA method.

In the present study, the influence of the heat treatment $\left(400{ }^{\circ} \mathrm{C}\right.$ or $\left.600{ }^{\circ} \mathrm{C}\right)$ on the corrosion resistance of the Al- $\mathrm{Cu}$ coating was investigated. The coating was produced on the Al substrate by the electrical discharge alloying (EDA) method. Before and after heat treatment the microstructure, mechanical properties and corrosion resistance of the materials were carried out by using of the electrochemical methods.

\section{Materials and Methods}

The aluminum-copper coatings on the aluminum $(99.8 \% \mathrm{Al})$ substrate were produced by the electrical discharge alloying method. For this purpose, a homemade energy generator was used. During the EDA treatment $600 \mathrm{~V}$ electrical impulses were used, while the capacitors battery had a capacity of $250 \mu \mathrm{F}$. The discharge current was $5 \mathrm{~A}$. The electric discharge time was 20 milliseconds. The source of the coating material was a specially crafted copper $(99.8 \% \mathrm{Cu}$ ) electrode (erode) and the diameter of the copper wire was $5 \mathrm{~mm}$. Unfortunately, the chemical composition of the copper electrode lagging is unknown. What is more, helium $(99.8 \% \mathrm{He})$ was used as a protective gas. However, the coating production efficiency was $150-170 \mathrm{mg} \mathrm{cm}^{-2}$.

Figure 2 shows a photograph image of the $\mathrm{Al} / \mathrm{Cu}$ alloy surface produced by the electrical discharge alloying (EDA) method. It is clear that the surface of the $\mathrm{Al} / \mathrm{Cu}$ alloy was rough, but there were no 
microcracks, scratches and delamination. Moreover, all copper layers were applied three times on the aluminum surface. The standard thickness of the Al-Cu coatings ranged from 30 to $50 \mu \mathrm{m}$.

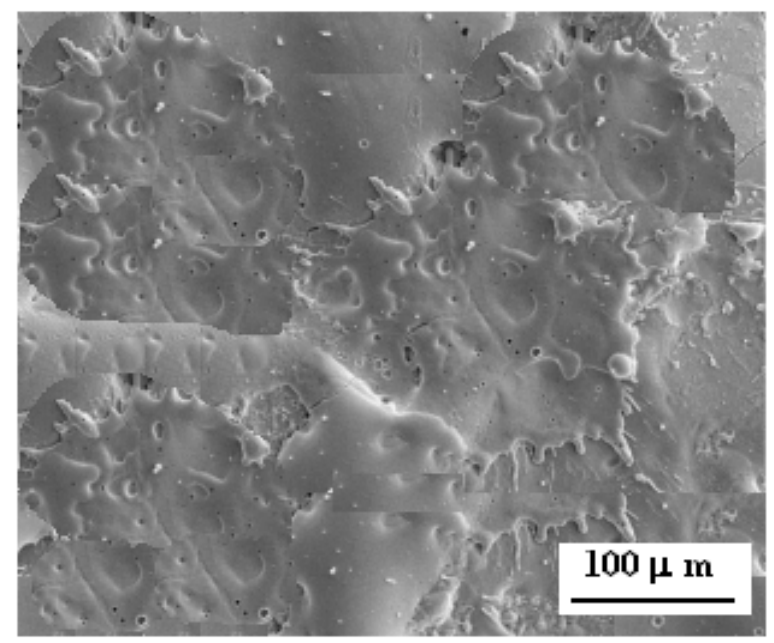

Figure 2. Photograph image of $\mathrm{Al} / \mathrm{Cu}$ surface produced by the electrical discharge alloying method.

The cross-section and microstructure of the specimens were observed by using a scanning electron microscope (SEM) Joel (Tokyo, Japan), type JSM-5400. The accelerating voltage of SEM was $20 \mathrm{kV}$. The chemical composition for the alloy surface was also measured by an energy-dispersive spectrometer (EDS).

The X-ray patterns diffraction (XRD; Carl Zeiss Jena, Germany), type HZG4 was used to characterize the phase composition of materials the monochromatic $\mathrm{Cu}, \mathrm{K} \alpha$ radiation source was $0.15407 \mathrm{~nm}$ at $30 \mathrm{kV}$ and $15 \mathrm{~mA}$ with a step scan mode at intervals of $0.05^{\circ}$ in $2 \theta$.

The measurement of microhardness of the tested materials was measured by the Vickers method, using the Falcon 500 hardness tester the INNOVATEST company (Maastricht, The Netherlands). An indenter was used in the form of a diamond pyramid with a square base and an angle between opposite walls equal to $136^{\circ}$ whose was load varied from 0.02 to $20 \mathrm{~N}$. The depth of indentation was about $2 \mu \mathrm{m}$.

For the heat treatment (thermogravimetric test) of the $\mathrm{Al} / \mathrm{Cu}$ alloy an electric chamber furnace (CZYLOK, Jastrzebie Zdroj, Poland), type FCF 2.5 HM was used. The heat treatment of materials was carried out in air atmosphere at $400{ }^{\circ} \mathrm{C}$ or $600{ }^{\circ} \mathrm{C}$. However, the heat treatment temperature of the specimens was below the melting point of aluminum, i.e., $660^{\circ} \mathrm{C}$. The weight change of the samples was monitored each time after one hour of heating. The heat treatment duration of the Al/Cu alloy was $9 \mathrm{~h}$.

All electrochemical measurements (corrosion tests) were carried out by using PGSTAT $128 \mathrm{~N}$ (AutoLab, Amsterdam, The Netherlands) potentiostat/galvanostat, piloted by NOVA 1.7 software (AutoLab, Amsterdam, The Netherlands). The electrochemical experiments were carried out in a conventional three-electrode cell.

The working electrode (stationary) was made of the $\mathrm{Al} / \mathrm{Cu}$ alloy without and after heat treatment at $400{ }^{\circ} \mathrm{C}$ or $600{ }^{\circ} \mathrm{C}$. The electrode material was mounted in a special holder. The geometric surface area of the working electrode was $1 \mathrm{~cm}^{2}$. Before each measurement the surface of the electrode was washed with bidistilled water, ultrasonically and dried at room temperature. Subsequently, the working electrode was immediately immersed in the test solution until a steady state was reached. The experiment was started after $30 \mathrm{~min}$ of immersion of the electrode in the corrosive solution.

The saturated calomel electrode (SCE) was used as the reference and the counter electrode $\left(9 \mathrm{~cm}^{2}\right)$ was made from platinum foil $(99.9 \% \mathrm{Pt})$. 
The corrosive environment (supporting electrolyte) was obtained by mixing the sodium chloride $\left(\mathrm{NaCl} ; \mathrm{POCH}\right.$, Poland) and hydrochloric acid ( $\mathrm{HCl}$; $\mathrm{POCH}$, Poland). The concentration of the $\mathrm{Cl}^{-}$ion was $1.2 \mathrm{M}$. The solvent used was three distilled water. The $\mathrm{pH}$ value was 1.5. The electrolyte was not deoxygenated.

The potentiodynamic polarization (LSV) curves were recorded. All measurements were carried out under a potential range from -1200 to $-200 \mathrm{mV}$ vs. SCE whereas the potential change rate was $1 \mathrm{mV} \mathrm{s}^{-1}$ with holding time of $30 \mathrm{~s}$ at $-1200 \mathrm{mV}$. In this way, the surface of the working electrode was cleaned because the metal oxides adsorbed on the surface were reduced.

The LSV curves were used to designate the corrosion electrochemical parameters, i.e., corrosion potential $\left(E_{\text {corr }}\right)$, corrosion current density $\left(j_{\text {corr }}\right)$ and slope a cathodic $\left(b_{c}\right)$ and anodic $\left(b_{\mathrm{a}}\right)$ branches of polarization curves. However, to determine the corrosion parameters and polarization resistance of the tested materials the Tafel Slope Analysis was used. More information about the Tafel method can be found in our publications $[25,26]$. However, for large cathodic overpotentials $\left(\eta / b_{c}<<-1\right)$ the Tafel equation for the cathodic reaction is given by:

$$
\eta=\log \left(j_{\text {corr }}\right)-b_{\mathrm{c}} \log |\mathbf{j}|
$$

Analogously, for large anodic overpotentials $\left(\eta / b_{\mathrm{a}}>>1\right)$ the Tafel equation for the anodic reaction is:

$$
\eta=\log \left(j_{\text {corr }}\right)+b_{\mathrm{a}} \log (j)
$$

where $\eta$ is defined as the difference between the applied potential and the corrosion potential (i.e., $\eta=E-E_{\text {corr }}$ ) and $j$ is the measured current density. The Tafel equations predict a straight line for the variation of the logarithm of current density with potential (Tafel plots).

The electrochemical corrosion rate of materials were appointed using the following equation:

$$
v_{\text {corr }}=3.268 \times \frac{j_{\text {corr } M}}{n \rho}
$$

where $j_{\text {corr }}$ is the corrosion current density (which was determined by the Tafel slope analysis method), $M$ is the molecular weight of reacting substrate, $n$ is the number of electrons exchanged and $\rho$ is the density of material.

The corrosion electrochemical parameters for the tested materials were determined as the average value based on three measurements.

The chronoamperometric curves $(C h A)$ were obtained for the potential values, which were selected on the basis of the potentiodynamic polarization curves. The values of the working electrode potential were carefully selected so as to observe a change in the current density values for the characteristic points on the LSV curves. For this purpose, three values of the working electrode potential were chosen for each material tested (i.e., one potential value concerned the cathodic process and two the anodic process). On this basis, it is possible to define the anticorrosive effect of metal coatings, in this case of the Al-Cu coatings on the aluminum substrate.

All electrochemical measurements were carried out at a temperature of $25 \pm 0.5^{\circ} \mathrm{C}$, which were maintained using an air thermostat.

\section{Results and Discussion}

\subsection{Microstructure of Materials}

Figure 3 shows an example the metallographic microstructure of cross-section of the $\mathrm{Al} / \mathrm{Cu}$ alloy and the results of $X$-ray microanalysis (with the line scanning) of the chemical elements distribution of the alloy and substrate. 
a)

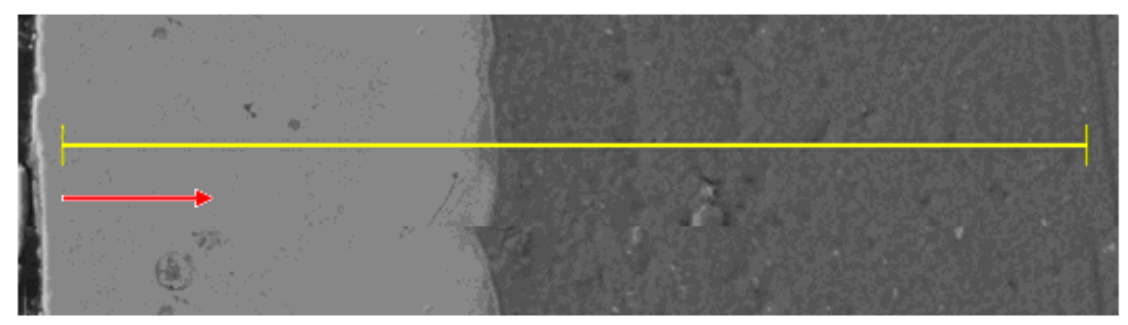

b)

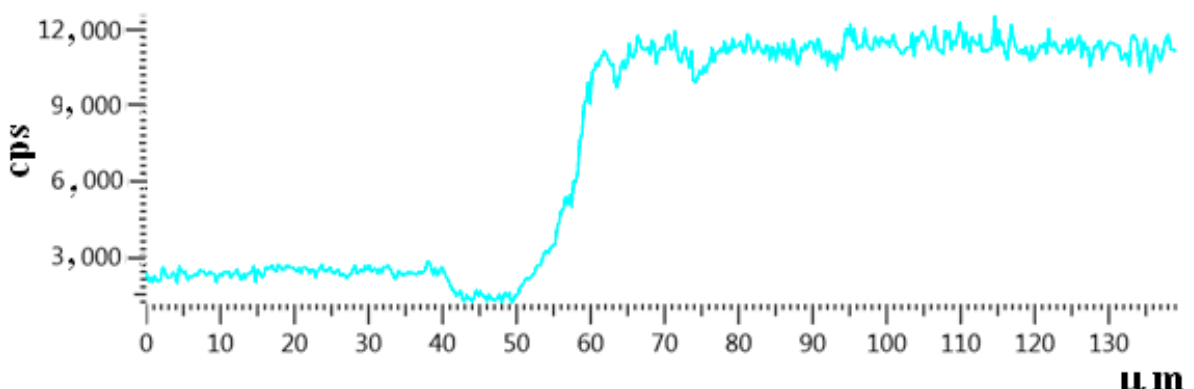

c)

$\boldsymbol{\mu} \mathbf{m}$

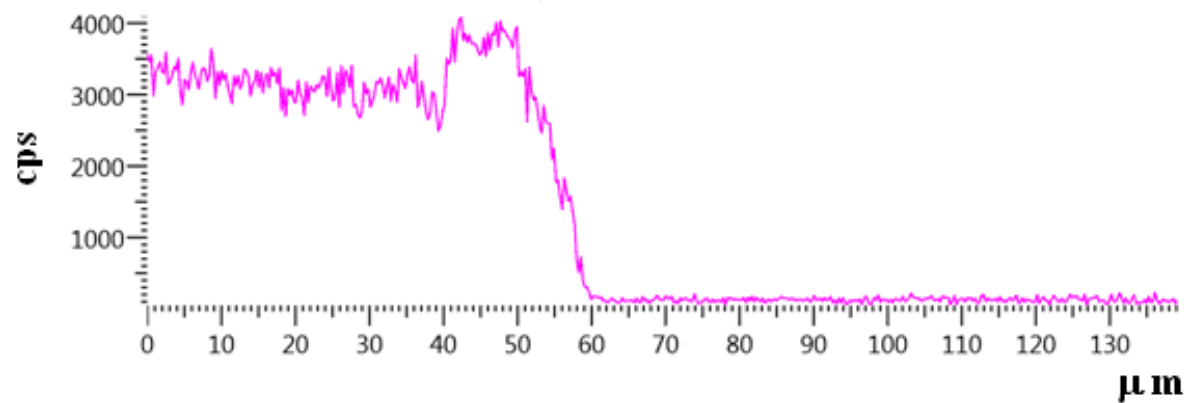

Figure 3. X-ray microanalysis of cross-section of $\mathrm{Al} / \mathrm{Cu}$ alloy: (a) metallographic microstructure (with the line scanning) and content distribution: (b) aluminum and (c) copper.

It turned out that by using the EDA method, diffused copper coatings on the aluminum surface were obtained. What is more, the $\mathrm{Al} / \mathrm{Cu}$ layer adhered well to the $\mathrm{Al}$ substrate. Figure 4 depicts the $\mathrm{SEM} / \mathrm{EDS}$ image of cross-section of the $\mathrm{Al} / \mathrm{Cu}$ alloy and the results of point $\mathrm{X}$-ray microanalysis of the chemical composition of the tested alloy.

It was found that of the $\mathrm{Al} / \mathrm{Cu}$ alloy contained an average of $31 \% \mathrm{Al}$ and $68 \% \mathrm{Cu}$ (Figure 4 ). It is worth adding that the Al-Cu coating contained trace amounts of other elements, i.e., $\mathrm{Zn}, \mathrm{Cd}$ and $\mathrm{Mg}$. It should be assumed that a large part of copper in the tested layer would significantly improve the corrosion resistance and mechanical properties of aluminum.

Figure 5 presents the XRD patterns for the $\mathrm{Al} / \mathrm{Cu}$ alloy. Intermetallic compounds composed of the $\mathrm{Al}$ phase and $\mathrm{Cu}$ phase as well as $\mathrm{CuAl}_{2}$ and $\mathrm{Cu}_{9} \mathrm{Al}_{4}$ phases were detected in the XRD patterns of the $\mathrm{Al} / \mathrm{Cu}$ alloy. Moreover, in the $\mathrm{Al} / \mathrm{Cu}$ alloy the natural air-formed oxide layer on the aluminum surface was removed by the micro-plasma generated between particles during the electrical discharge alloying process. In addition, the formation of intermetallic compounds was induced by the activation of intermetallic reactions by local high temperatures.

Therefore, in high temperature conditions (between 400 and $1200{ }^{\circ} \mathrm{C}$ ) the following chemical reactions are possible on the aluminum surface:

$$
2 \mathrm{Al}+\mathrm{Cu} \rightarrow \mathrm{CuAl}_{2}
$$




$$
\begin{gathered}
\mathrm{Al}+\mathrm{Cu} \rightarrow \mathrm{CuAl} \\
4 \mathrm{Al}+9 \mathrm{Cu} \rightarrow \mathrm{Cu}_{9} \mathrm{Al}_{4} .
\end{gathered}
$$

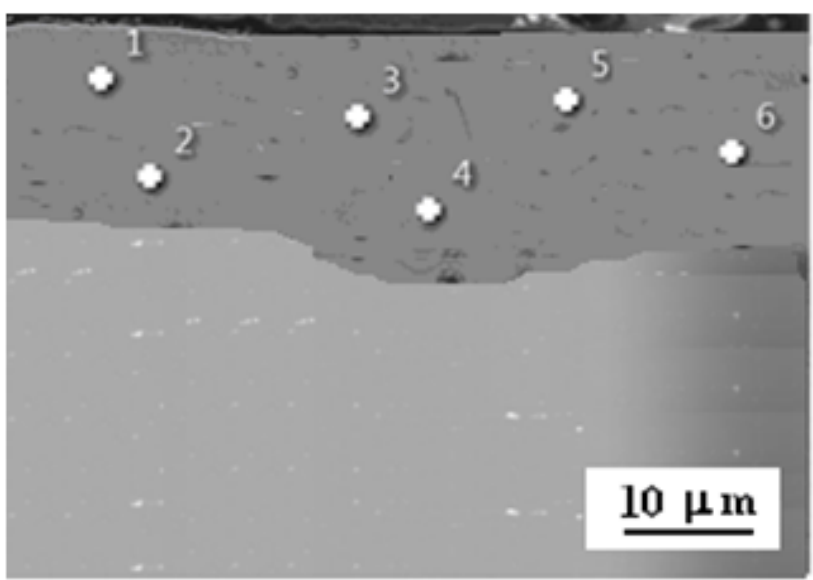

\begin{tabular}{|l|c|c|}
\hline \multirow{2}{*}{$\begin{array}{l}\text { Spectrum } \\
\text { label }\end{array}$} & Al & Cu \\
\cline { 2 - 3 } & \multicolumn{2}{|c|}{ Weight $\%$} \\
\hline Spectrum 1 & 34.0 & 65.2 \\
\hline Spectrum 2 & 35.2 & 63.7 \\
\hline Spectrum 3 & 40.9 & 58.0 \\
\hline Spectrum 4 & 23.3 & 75.7 \\
\hline Spectrum 5 & 30.1 & 68.4 \\
\hline Spectrum 6 & 23.0 & 76.6 \\
\hline
\end{tabular}

Figure 4. Scanning electron microscopy (SEM) micrograph and energy-dispersive spectroscopy (EDS) for $\mathrm{Al} / \mathrm{Cu}$ alloy and the results of point $\mathrm{X}$-ray microanalysis of the chemical composition of the tested alloy.

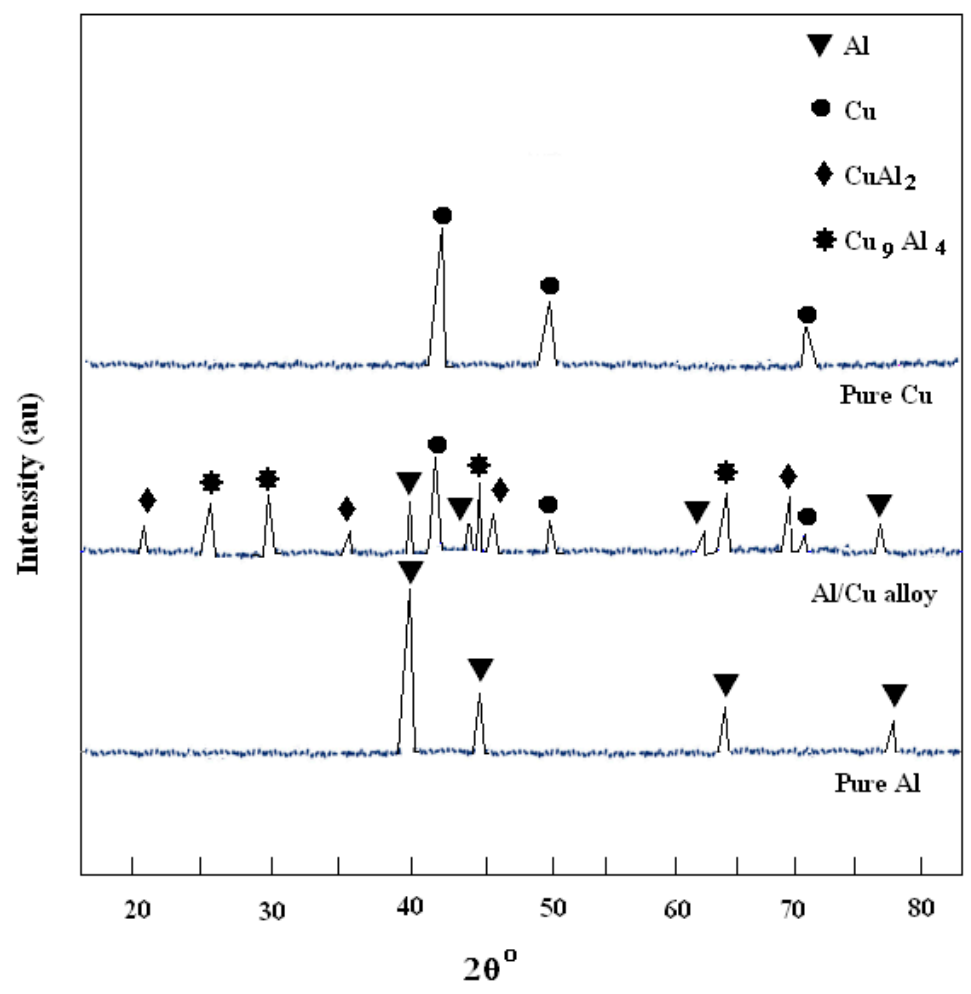

Figure 5. XRD diffractogram of the $\mathrm{Al}, \mathrm{Cu}$ and $\mathrm{Al} / \mathrm{Cu}$ alloy.

A similar mechanism of chemical reactions (4)-(6) was also proposed by the authors of the work [13]. Moreover, according to the standard Gibbs free energy of formation values for chemical reactions (4)-(6) they are all forward reactions, indicating the possibility for the formation of intermetallic compounds. The heats of formation for the phases in these chemical reactions are: $\mathrm{CuAl}_{2}:-6.1 \mathrm{~kJ} \mathrm{~mol}^{-1}, \mathrm{CuAl}$ : $-5.1 \mathrm{~kJ} \mathrm{~mol}^{-1}$ and $\mathrm{Cu}_{9} \mathrm{Al}_{4}:-4.1 \mathrm{~kJ} \mathrm{~mol}^{-1}[27,28]$. Furthermore, the heats of the formation for these intermetallic compounds can thus be arranged in order from smallest to largest as: $\mathrm{CuAl}_{2}, \mathrm{CuAl}$ and $\mathrm{Cu}_{9} \mathrm{Al}_{4}$. Therefore, the $\mathrm{CuAl}_{2}$ phase will be formed first (reaction (4)), followed by $\mathrm{CuAl}$ (reaction (5)) 
and $\mathrm{Cu}_{9} \mathrm{Al}_{4}$ (reaction (6)). However, in the XRD diffraction patterns for the $\mathrm{Al} / \mathrm{Cu}$ alloy (Figure 5) only the $\mathrm{CuAl}_{2}$ and $\mathrm{Cu}_{9} \mathrm{Al}_{4}$ phases were detected. Moreover, the $\mathrm{CuAl}$ phase was not observed. Probably, the $\mathrm{Cu}$ and $\mathrm{Al}$ atoms more readily diffuse into the $\mathrm{Cu}_{9} \mathrm{Al}_{4}$ phase and the $\mathrm{CuAl}$ phase and other are not formed on the $\mathrm{Al} / \mathrm{Cu}$ surface.

\subsection{Vickers Hardness of Materials}

The hardness values of aluminum, copper and $\mathrm{Al} / \mathrm{Cu}$ alloy are listed in Table 1.

Table 1. Vickers hardness of aluminum, copper and $\mathrm{Al} / \mathrm{Cu}$ alloy surface.

\begin{tabular}{cccc}
\hline Material & Aluminum & Copper & Al/Cu Alloy \\
\hline Hardness, HV20 & $29.2 \pm 0.04$ & $58.7 \pm 0.02$ & $123.3 \pm 0.01$ \\
\hline
\end{tabular}

The Vickers hardness of the $\mathrm{Al} / \mathrm{Cu}$ alloy was about $123.3 \mathrm{HV} 20$, which is approximately four times greater than that of $\mathrm{Al}$ and about two times greater than that of $\mathrm{Cu}$ (Table 1). It is suggested that this strengthening of the $\mathrm{Al} / \mathrm{Cu}$ alloy was affected by the presence of the intermetallic compounds such as $\mathrm{CuAl}_{2}$ and $\mathrm{Cu}_{9} \mathrm{Al}_{4}$, which were formed through reactions ((5) and (6)) between $\mathrm{Al}$ and $\mathrm{Cu}$ during the electrical discharge alloying process. Therefore, at a higher temperature $\mathrm{Al}$ and $\mathrm{Cu}$ will react to form intermetallic compounds and these compounds have a much higher hardness, thus resulting in a significant increase in the hardness at the $\mathrm{Al} / \mathrm{Cu}$ alloy.

\subsection{Thermogravimetric Test}

The thermogravimetric test was considered in registering the weight gain of the tested materials $(W=\Delta m / A)$, as a function of exposure time at a certain temperature (i.e., $\Delta m / A=f(t))$ [29]. In this case the heat treatment of the $\mathrm{Al} / \mathrm{Cu}$ alloy was carried out at $400{ }^{\circ} \mathrm{C}$ or $600{ }^{\circ} \mathrm{C}$ in the air atmosphere the exposure time was 9 h, Figure 6.

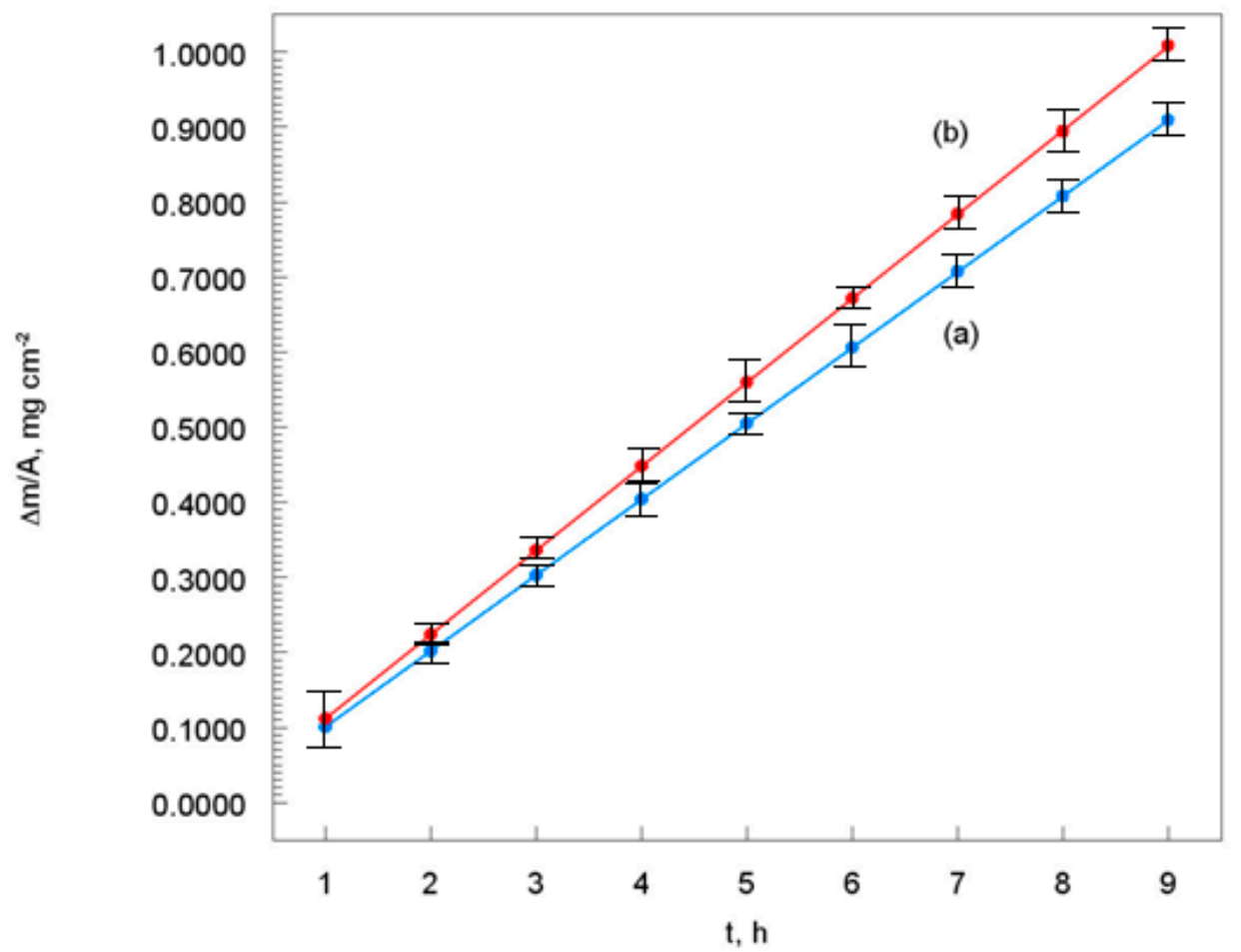

Figure 6. Influence of exposure time on mass change of $\mathrm{Al} / \mathrm{Cu}$ alloy during heat treatment at: (a) $400{ }^{\circ} \mathrm{C}$ or (b) $600{ }^{\circ} \mathrm{C}$ in air atmosphere. Exposure time $9 \mathrm{~h}$. 
In temperature conditions $\left(400^{\circ} \mathrm{C}\right.$ or $\left.600{ }^{\circ} \mathrm{C}\right)$ in air atmosphere the process of chemical corrosion (oxidation) of the $\mathrm{Al} / \mathrm{Cu}$ alloy proceed according to the linear law: $W=k t+C$, which was characteristic for the metals whose oxide surface was porous [30]. The kinetic equation that described the oxidation of the $\mathrm{Al} / \mathrm{Cu}$ alloy for a temperature of $400{ }^{\circ} \mathrm{C}$ (Figure 6, curve (a)) is:

$$
W=0.10 t+2.08 \times 10^{-4}
$$

However, for a temperature of $600{ }^{\circ} \mathrm{C}$ (Figure 6, curve (b)) the linear law is:

$$
W=0.11 t+2.78 \times 10^{-4}
$$

Therefore, of the $\mathrm{Al} / \mathrm{Cu}$ alloy surface in hot air conditions was covered with a porous oxide layer, which does not constitute an effective obstacle in the access of the oxidant to the deeper layers of the coating. The oxidation process of the $\mathrm{Al} / \mathrm{Cu}$ alloy surface is described by the equations:

$$
\begin{gathered}
4 \mathrm{Al}+3 \mathrm{O}_{2} \rightarrow 2\left(\mathrm{Al}_{2} \mathrm{O}_{3}\right)_{\mathrm{ads}} \\
2 \mathrm{Cu}+\mathrm{O}_{2} \rightarrow 2(\mathrm{CuO})_{\mathrm{ads}}
\end{gathered}
$$

A complex oxide layer formed on the surface of the $\mathrm{Al} / \mathrm{Cu}$ alloy, i.e., $\left(\mathrm{Al}_{2} \mathrm{O}_{3}\right)_{\text {ads }}$ and $(\mathrm{CuO})_{\mathrm{ads}}$ (reactions (9) and (10)). Moreover, the weight gain of the $\mathrm{Al} / \mathrm{Cu}$ alloy was clearly greater if the heat treatment temperature was $600{ }^{\circ} \mathrm{C}$ (Figure 6). Therefore, the oxide layer on the surface of the $\mathrm{Al} / \mathrm{Cu}$ alloy that was subjected to heat treatment at $600^{\circ} \mathrm{C}$ was thicker compared to the $\mathrm{Al} / \mathrm{Cu}$ alloy that was subjected to heating in hot air conditions at $400{ }^{\circ} \mathrm{C}$ The effect of the heat treatment temperature on the thickness of the oxide layer on the surface of the $\mathrm{Al} / \mathrm{Cu}$ alloy will be discussed later in this work.

The Vickers hardness values of the $\mathrm{Al} / \mathrm{Cu}$ alloy surface after heat treatment in the air atmosphere are listed in Table 2.

Table 2. Vickers hardness of $\mathrm{Al} / \mathrm{Cu}$ alloy surface after heat treatment.

\begin{tabular}{cc}
\hline $\begin{array}{c}\text { Heat Treatment Temperature } \\
{ }^{\circ} \mathbf{C}\end{array}$ & $\begin{array}{c}\text { Hardness } \\
\text { HV20 }\end{array}$ \\
\hline 400 & $147.9 \pm 0.03$ \\
600 & $108.8 \pm 0.15$ \\
\hline
\end{tabular}

The Vickers hardness of the $\mathrm{Al} / \mathrm{Cu}$ alloy after heat treatment at $400{ }^{\circ} \mathrm{C}$ was more than $25 \mathrm{HV} 20$ higher compared to the $\mathrm{Al} / \mathrm{Cu}$ alloy without heat treatment (Table 1 ). However, after heat treatment of the $\mathrm{Al} / \mathrm{Cu}$ alloy at $600{ }^{\circ} \mathrm{C}$ the Vickers hardness of the alloy decreased significantly to $108.8 \mathrm{HV} 20$ (Table 2). A drastic reduction in the hardness of the $\mathrm{Al} / \mathrm{Cu}$ alloy was associated with a change in the structure of the alloy. This means that as a result of heat treatment of the $\mathrm{Al} / \mathrm{Cu}$ alloy at an elevated temperature in the air atmosphere the mechanical properties of the surface of the tested material deteriorated significantly.

\subsection{Scanning Electron Microscopy Images}

Figure 7 shows the scanning electron microscopy (SEM) images of the cross-sections of the samples, before (Figure 7a) and after heat treatment at $400{ }^{\circ} \mathrm{C}$ (Figure $7 \mathrm{~b}$ ) or $600{ }^{\circ} \mathrm{C}$ (Figure $7 \mathrm{c}$ ) in the air atmosphere. On the right side, enlarged selected fragments of Figure 7 were placed.

The cross-sections were etched with $10 \mathrm{wt} \% \mathrm{NaOH}$ water solution after polishing treatment, to make the splats and microstructure in them more visible.

The $\mathrm{Al} / \mathrm{Cu}$ alloy structure on the $\mathrm{Al}$ substrate was not homogeneous, small cracks and numerous craters were visible (Figure 7a). As a result of heat treatment at $400{ }^{\circ} \mathrm{C}$ the Al-Cu coating changed significantly. The $\mathrm{Al} / \mathrm{Cu}$ alloy surface was covered with a $\left(\mathrm{Al}_{2} \mathrm{O}_{3}-\mathrm{CuO}\right)_{\text {ads }}$ layer, whose thickness ranged 
from 4 to $5 \mu \mathrm{m}$ (Figure $7 \mathrm{~b}$ ). The oxide layer adhered well to the $\mathrm{Al} / \mathrm{Cu}$ surface. The $\mathrm{Al} / \mathrm{Cu}$ structure defects disappeared and the alloy became more compact. Therefore, the mechanical properties of the $\mathrm{Al} / \mathrm{Cu}$ alloy improved. Moreover, the grains of the aluminum substrate increased significantly. After heat treatment at $600{ }^{\circ} \mathrm{C}$ the thickness of the $\left(\mathrm{Al}_{2} \mathrm{O}_{3}-\mathrm{CuO}\right)_{\text {ads }}$ layer increased, reaching values from 8 to $10 \mu \mathrm{m}$ (Figure $7 \mathrm{c}$ ). The oxide layer cracked under the influence of elevated temperature. On the other hand of the $\left(\mathrm{Al}_{2} \mathrm{O}_{3}-\mathrm{CuO}\right)_{\text {ads }}$ layer lost its protective properties with respect to the $\mathrm{Al} / \mathrm{Cu}$ alloy. The thickness of the Al-Cu coating clearly decreased, but its structure did not crack. Therefore, despite the elevated temperature the $\mathrm{Al}-\mathrm{Cu}$ coating did not lose its protective properties in relation to the aluminum substrate. Furthermore, the grain size increased, and the aluminum structure changed.
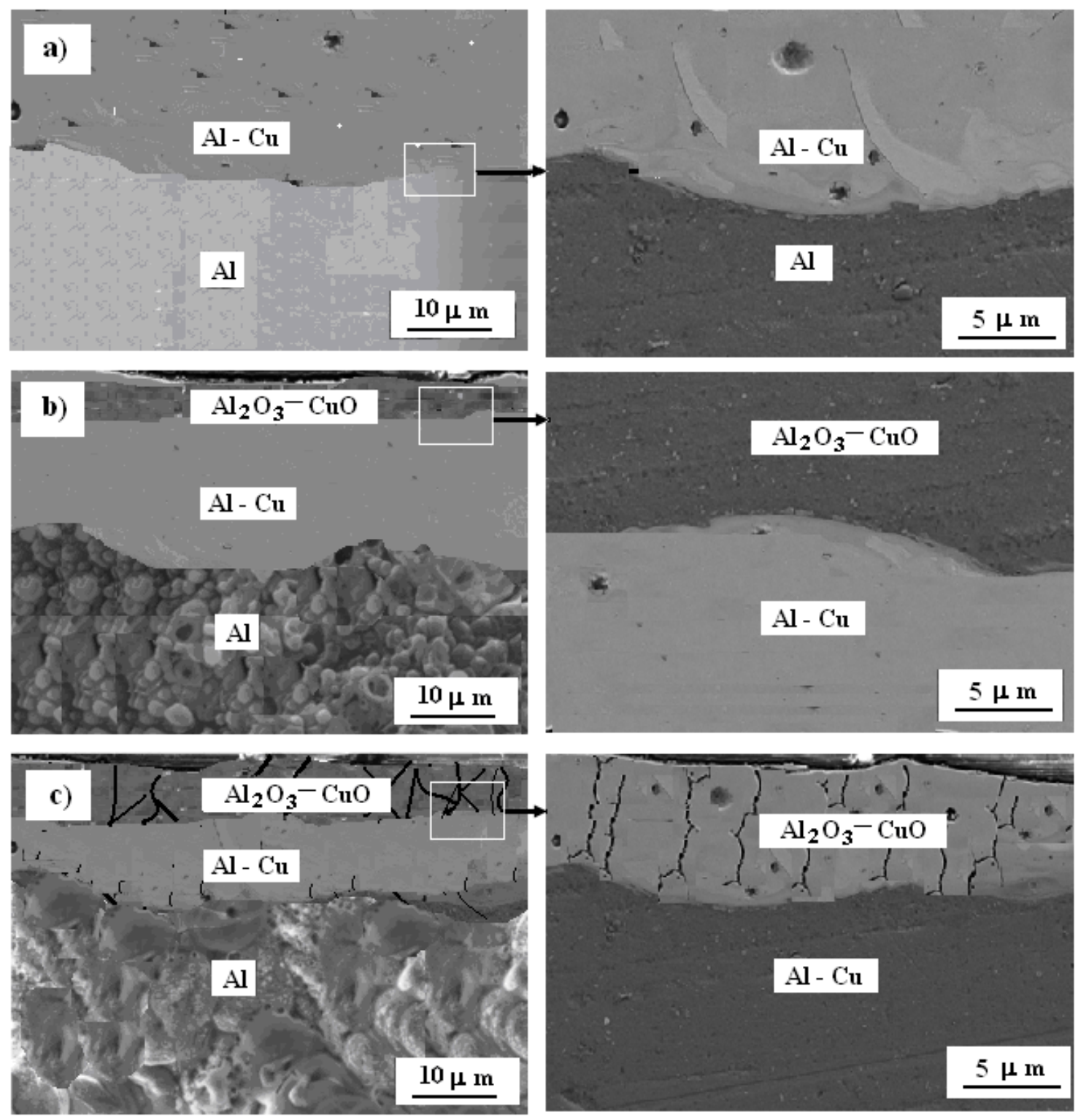

Figure 7. SEM images of cross-section of samples: (a) before and after heat treatment at: (b) $400{ }^{\circ} \mathrm{C}$ or (c) $600{ }^{\circ} \mathrm{C}$ in air atmosphere.

\subsection{Corrosion Test}

Potentiodynamic polarization (LSV) measurements were carried out in order to gain knowledge concerning the impact of heat treatment on the anticorrosion properties of the Al-Cu coating on the aluminum substrate and kinetics of the cathodic and anodic reactions. 
The potentiodynamic polarization curves for the $\mathrm{Al} / \mathrm{Cu}$ alloy were registered before and after heat treatment at $400{ }^{\circ} \mathrm{C}$ or $600^{\circ} \mathrm{C}$ in the air atmosphere, Figure 8 .

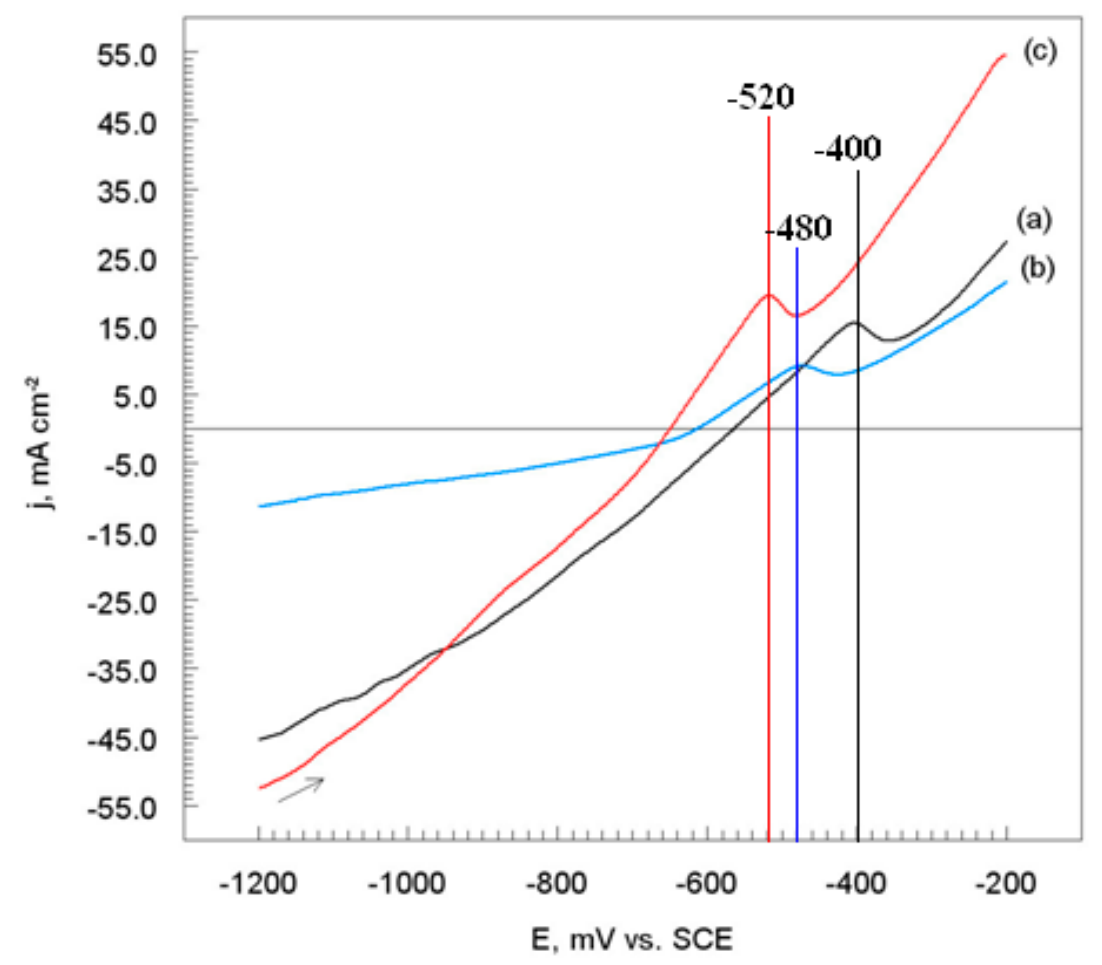

Figure 8. Potentiodynamic polarization curves of the $\mathrm{Al} / \mathrm{Cu}$ alloy: (a) before and after heat treatment at: (b) $400{ }^{\circ} \mathrm{C}$ or (c) $600{ }^{\circ} \mathrm{C}$. Solutions contained $1.2 \mathrm{M} \mathrm{Cl}^{-}, \mathrm{pH} 1.5, \mathrm{~d} E / \mathrm{d} t 1 \mathrm{mV} \mathrm{s}^{-1}$.

In the Figure 8, curve (a) refers to the $\mathrm{Al} / \mathrm{Cu}$ alloy that has not been heat treated. In the acid corrosive environment the cathodic branch correspond to the reduction of hydrogen ions [2,4]. In contrast, the anode part of the potentiodynamic polarization curve relates to the active dissolution of the electrode surface. For a potential of about $-400 \mathrm{mV}$ vs. SCE peak appeared on the curve, which corresponds to a weak passivation process of the $\mathrm{Al} / \mathrm{Cu}$ alloy surface. Thus, the electrode surface was covered with a layer of $\left(\mathrm{Al}_{2} \mathrm{O}_{3}\right)_{\text {ads }}$ and $(\mathrm{CuO})_{\text {ads }}$ oxides. In the acid chloride environment, the oxide layer dissolved, therefore the anode current density increased rapidly (Figure 8, curve (a)).

The curve (b) in the Figure 8 corresponds to the Al-Cu coating, which was subjected to heat treatment at $400{ }^{\circ} \mathrm{C}$. However, the anode current density decreased compared to the $\mathrm{Al} / \mathrm{Cu}$ alloy without heat treatment (Figure 8, curve (a)). In this case, the potential of the passivation peak shifted towards negative values, i.e., $-480 \mathrm{mV}$ vs. SCE. The structure of the oxide layer changed, and the $\left(\mathrm{Al}_{2} \mathrm{O}_{3}-\mathrm{CuO}\right)_{\text {ads }}$ layer effectively protected the $\mathrm{Al} / \mathrm{Cu}$ alloy from having contact with the aggressive corrosive environment. For a more positive electrode potential, the oxide protective layer dissolved and the anode current density increased rapidly (Figure 8, curve (b)).

The heat treatment at $600^{\circ} \mathrm{C}$ of the $\mathrm{Al} / \mathrm{Cu}$ alloy caused the significant disappearance of anticorrosive properties of the $\left(\mathrm{Al}_{2} \mathrm{O}_{3}-\mathrm{CuO}\right)_{\text {ads }}$ coating on the alloy surface. This is evidenced by the increase in the anode current density, Figure 8, curve (c). Moreover, on the LSV curve of the passivation peak appeared for the potential of $-520 \mathrm{mV}$ vs. SCE. Shifting the peak towards negative potential values means degradation of the oxide layer structure. However, the oxide layer did not effectively separate of the $\mathrm{Al} / \mathrm{Cu}$ alloy from the corrosive environment. 


\subsubsection{Corrosion Electrochemical Parameters}

The potentiodynamic polarization curves (Figure 8) for the $\mathrm{Al} / \mathrm{Cu}$ alloy produced by the electrical discharge alloying method were used to designate the corrosion electrochemical parameters before and after heat treatment in the air atmosphere. For this purpose the Tafel method was used. In this case, current density is often shown in semilogarithmic plots known as Tafel plots. Furthermore, this type of analysis is referred to as the Tafel slope analysis. In this case, we did not present a graphical form (Tafel plots) of the analysis of test results, which we put together in the form of Figure 8 . Analysis results as the corrosion electrochemical parameters of the Al-Cu coating on the aluminum substrate were listed in Table 3. Along with the increase in the temperature of the heat treatment of the $\mathrm{Al} / \mathrm{Cu}$ alloy, a shift (about $100 \mathrm{mV}$ ) of corrosion potential $\left(E_{\text {corr }}\right)$ towards negative values was observed. It is noteworthy that the value of corrosive current density $\left(j_{\text {corr }}\right)$ for the $\mathrm{Al} / \mathrm{Cu}$ alloy after heat treatment at $400{ }^{\circ} \mathrm{C}$ clearly decreased to about $2 \mathrm{~mA} \mathrm{~cm}^{-2}$ compared to an alloy that has not been heat treated (Table 3). As a result of thermal treatment, the corrosion resistance of the $\mathrm{Al} / \mathrm{Cu}$ alloy was significantly improved. After the heat treatment of the Al-Cu coating at elevated temperature, i.e., $600{ }^{\circ} \mathrm{C}$ the corrosion current density increased three times compared to the Al-Cu coating that was treated at $400{ }^{\circ} \mathrm{C}$ (Table 3). This means that as a result of heat treatment at $600{ }^{\circ} \mathrm{C}$ corrosion resistance of the Al-Cu coating on the aluminum substrate significantly deteriorated.

The cathodic $\left(b_{\mathrm{c}}\right)$ and anodic $\left(b_{\mathrm{a}}\right)$ Tafel slope was changed as a result of an increase in the heat treatment temperature of the $\mathrm{Al} / \mathrm{Cu}$ alloy on the $\mathrm{Al}$ substrate (Table 3). This means that the mechanism of cathodic and anodic reactions depends on the temperature of the thermal treatment of the $\mathrm{Al} / \mathrm{Cu}$ alloy in the air atmosphere.

Table 3. Corrosion electrochemical parameters of the $\mathrm{Al} / \mathrm{Cu}$ alloy on the $\mathrm{Al}$ substrate.

\begin{tabular}{|c|c|c|c|c|}
\hline \multirow{2}{*}{$\begin{array}{l}\text { Heat Treatment Temperature } \\
{ }^{\circ} \mathrm{C}\end{array}$} & \multirow{2}{*}{$\begin{array}{c}\mathrm{E}_{\text {corr }} \\
\text { mV vs. SCE }\end{array}$} & \multirow{2}{*}{$\begin{array}{c}\mathrm{j}_{\mathrm{corr}} \\
\mathrm{mA} \mathrm{cm}\end{array}$} & $-\mathbf{b}_{\mathrm{c}}$ & $b_{a}$ \\
\hline & & & \multicolumn{2}{|c|}{$\mathrm{mV} \mathrm{\operatorname {dec } ^ { - 1 }}$} \\
\hline Before & -564 & 2.9 & 210 & 290 \\
\hline 400 & -614 & 2.0 & 505 & 175 \\
\hline 600 & -650 & 6.0 & 330 & 235 \\
\hline
\end{tabular}

\subsubsection{Corrosion Rate and Polarization Resistance}

The polarization resistance $(\mathrm{Rp})$ of the Al-Cu coatings was determined on the basis of the slope of potentiodynamic polarization curves (Figure 8) and is summarized in Table 4.

Table 4. Polarization resistance and corrosion rate of the $\mathrm{Al} / \mathrm{Cu}$ alloy on the $\mathrm{Al}$ substrate.

\begin{tabular}{|c|c|c|}
\hline $\begin{array}{l}\text { Heat Treatment Temperature } \\
{ }^{\circ} \mathrm{C}\end{array}$ & $\begin{array}{c}R_{\mathrm{p}} \\
\left(\mathrm{k} \Omega \mathrm{cm}^{2}\right)\end{array}$ & $\begin{array}{c}v_{\text {corr }} \\
\left(\mathrm{mm}_{\text {year }}{ }^{-1}\right)\end{array}$ \\
\hline Before & 18 & 33 \\
\hline 400 & 28 & 23 \\
\hline 600 & 10 & 68 \\
\hline
\end{tabular}

It was found that as a result of heat treatment of the $\mathrm{Al} / \mathrm{Cu}$ surface the $\mathrm{Rp}$ reached values about $28 \mathrm{k} \Omega \mathrm{cm}^{2}$, which is clearly higher than the Al-Cu coating before heat treatment at $400{ }^{\circ} \mathrm{C}$ (Table 4). Thus, heat treatment at $400{ }^{\circ} \mathrm{C}$ significantly increased the anticorrosion properties of the Al-Cu coating in the aggressive chloride environment. However, an increase in temperature to $600{ }^{\circ} \mathrm{C}$ significantly reduced (three times) the anticorrosive properties of the Al-Cu coating (Table 4), which means that in this case the exchange of mass and charge between the electrode and the electrolyte solution was not slowed down during the corrosion process.

The electrochemical corrosion rate of the Al-Cu coating was calculated based on the equation (3) and listed in Table 4. For this purpose, the corrosion current density ( $j_{\text {corr }}$ ) values of $\mathrm{Al}$ and $\mathrm{Cu}$ 
were calculated depending on their content in the $\mathrm{Al} / \mathrm{Cu}$ alloy (i.e., $31 \% \mathrm{Al}$ and $68 \% \mathrm{Cu}$ ). Therefore, the corrosion rate of the $\mathrm{Al} / \mathrm{Cu}$ alloy should be expressed as the sum of the corrosion rate of the alloy components i.e., aluminum and copper. The corrosion rate of the $\mathrm{Al} / \mathrm{Cu}$ alloy after heat treatment at $400{ }^{\circ} \mathrm{C}$ was about one and a half lower compared to the $\mathrm{Al} / \mathrm{Cu}$ alloy without heat treatment (Table 4). However, the oxide layer, i.e., $\left(\mathrm{Al}_{2} \mathrm{O}_{3}\right)_{\text {ads }}$ and $(\mathrm{CuO})_{\text {ads }}$ protected of the $\mathrm{Al} / \mathrm{Cu}$ alloy surface against corrosion in the aggressive chloride environment.

On the other hand after heat treatment of the $\mathrm{Al} / \mathrm{Cu}$ alloy at the temperature of $600^{\circ} \mathrm{C}$ the corrosion rate increased more than three times compared to the $\mathrm{Al} / \mathrm{Cu}$ alloy, which was annealed at $400{ }^{\circ} \mathrm{C}$ (Table 4). This suggests that the $\left(\mathrm{Al}_{2} \mathrm{O}_{3}-\mathrm{CuO}\right)_{\text {ads }}$ layer is not tight and does not protect of the $\mathrm{Al} / \mathrm{Cu}$ alloy against corrosion.

\subsection{Chronoamperometric Measurement}

Figures 9 and 10 show chronoamperometric ( $C h A)$ curves for the $\mathrm{Cu}$ coatings on the $\mathrm{Al}$ substrate, after heat treatment at $400{ }^{\circ} \mathrm{C}$ or $600{ }^{\circ} \mathrm{C}$ in the air atmosphere. The potentials of the working electrode were selected according to the potentiodynamic polarization curves (Figure 8, curves (b) and (c)). The exposure time of specimens in the chloride environment $\left(1.2 \mathrm{M} \mathrm{Cl}^{-}\right)$was five minutes. However, similar $\mathrm{ChA}$ curves were recorded for the $\mathrm{Al} / \mathrm{Cu}$ alloy without heat treatment, but they were not cited in this work.

The curves (a) relate to the reduction of hydrogen ions on the surface of the working electrode [2,4]. In the case of the $\mathrm{Al} / \mathrm{Cu}$ electrode after heat treatment at $400{ }^{\circ} \mathrm{C}$ an inhibitory effect of the $\left(\mathrm{Al}_{2} \mathrm{O}_{3}-\mathrm{CuO}\right)_{\mathrm{ads}}$ layer was observed. This means that the $\left(\mathrm{Al}_{2} \mathrm{O}_{3}-\mathrm{CuO}\right)_{\text {ads }}$ coating was tight and the hydrogen ion reduction process was slowed down during electrolysis in the chloride environment (Figure 9, curve (a)). On the other hand after the heat treatment of the $\mathrm{Al} / \mathrm{Cu}$ alloy at $600{ }^{\circ} \mathrm{C}$ a non-tight oxide layer was obtained. Therefore, the current density resulting from the hydrogen ion reduction reaction increased with increasing electrolysis time (Figure 10, curve (a)).

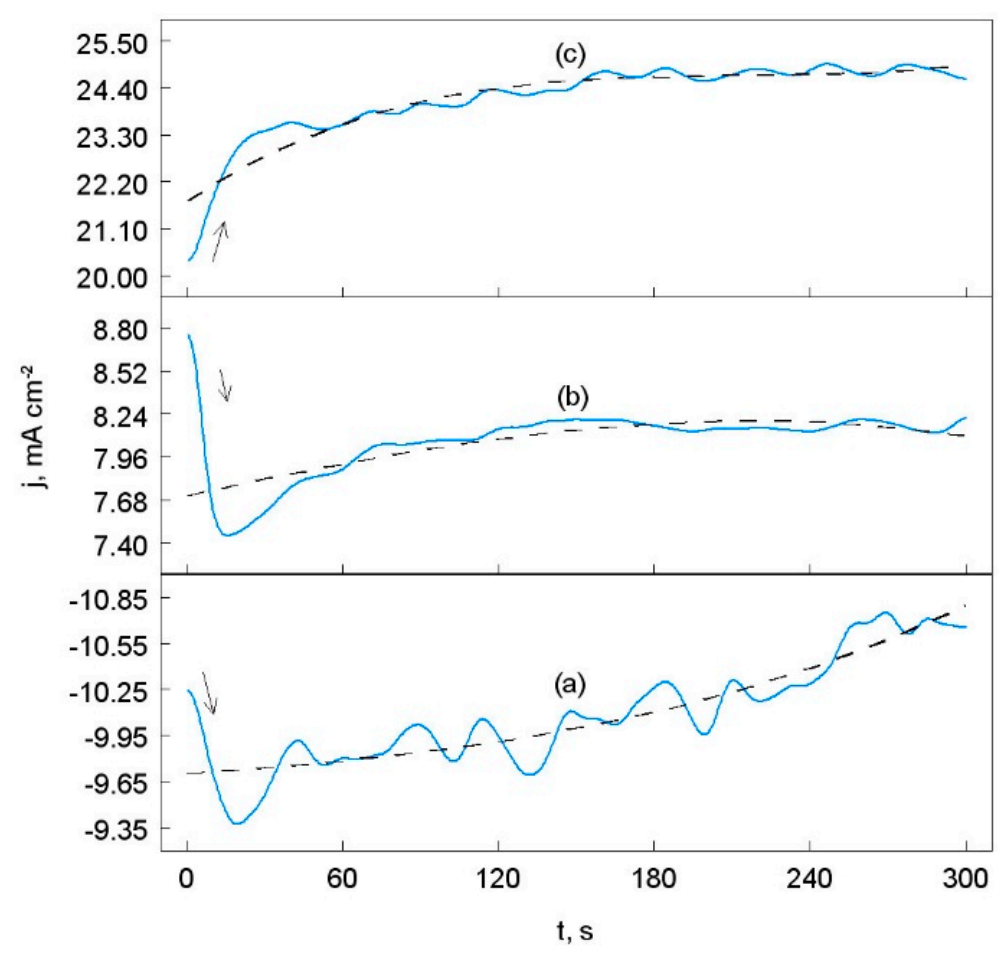

Figure 9. Chronoamperometric curves of the $\mathrm{Al} / \mathrm{Cu}$ alloy after heat treatment at $400{ }^{\circ} \mathrm{C}$, obtained for: (a) $-950 \mathrm{mV},(\mathbf{b})-420 \mathrm{mV}$ and (c) $-300 \mathrm{mV}$ vs. the saturated calomel electrode (SCE). Solution contained $1.2 \mathrm{M} \mathrm{Cl}^{-}$, pH 1.5 (dashed lines refer to the average current density values). 


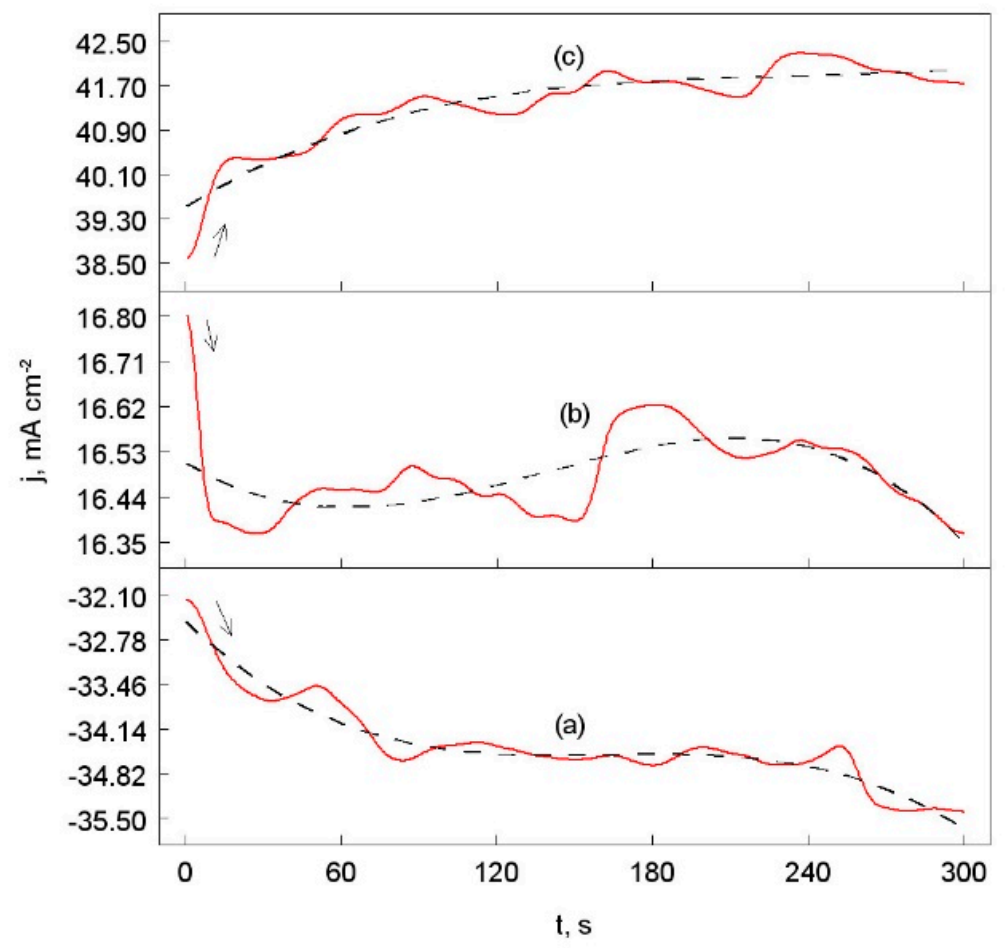

Figure 10. Chronoamperometric curves of the $\mathrm{Al} / \mathrm{Cu}$ alloy after heat treatment at $600{ }^{\circ} \mathrm{C}$, obtained for: (a) $-950 \mathrm{mV},(\mathbf{b})-480 \mathrm{mV}$ and (c) $-300 \mathrm{mV}$ vs. SCE. Solution contained $1.2 \mathrm{M} \mathrm{Cl}^{-}, \mathrm{pH} 1.5$ (dashed lines refer to the average current density values).

The curves (b) should be attributed to the oxidation of the Al-Cu coatings. It has been observed that for the $\mathrm{Al}-\mathrm{Cu}$ coating after heat treatment at $400{ }^{\circ} \mathrm{C}$ the anode current density associated with the oxidation of the electrode material remained constant (approximately $8.20 \mathrm{~mA} \mathrm{~cm}^{-2}$; Figure 9, curve (b)). It was confirmed that the oxide layer was tight and well protected for the Al-Cu coating against electrochemical corrosion under experimental conditions. For the Al-Cu coating after heat treatment at $600{ }^{\circ} \mathrm{C}$ the anode current density that was associated with the oxidation of the alloy tested varied from 16.40 to $16.55 \mathrm{~mA} \mathrm{~cm}^{-2}$ (Figure 10, curve (b)). So, under an elevated temperature, i.e., $600{ }^{\circ} \mathrm{C}$, the structure of the $\left(\mathrm{Al}_{2} \mathrm{O}_{3}-\mathrm{CuO}\right)_{\text {ads }}$ coating was significantly damaged and did not separate of the $\mathrm{Al} / \mathrm{Cu}$ alloy before contact with a corrosive environment.

The curves (c) for the tested materials were recorded for a more positive potential value, i.e., $-300 \mathrm{mV}$ vs. SCE.

In this case, regardless of the temperature (i.e., $400{ }^{\circ} \mathrm{C}$ or $600{ }^{\circ} \mathrm{C}$ ) of the heat treatment of the tested materials the anode current density increased systematically during electrolysis (Figures 9 and 10, curves (c)). The $\left(\mathrm{Al}_{2} \mathrm{O}_{3}-\mathrm{CuO}\right)_{\text {ads }}$ was not an effective barrier to protect of the $\mathrm{Al}-\mathrm{Cu}$ coating from oxidation in the aggressive chloride environment.

\subsection{Photograph Images after the Corrosion Test}

Figure 11 shows the photograph images of the $\mathrm{Al} / \mathrm{Cu}$ surface produced by the electrical discharge alloying method before (Figure 11a) and after heat treatment at $400^{\circ} \mathrm{C}$ (Figure 11b) or $600{ }^{\circ} \mathrm{C}$ (Figure 11c) in air atmosphere and after the corrosion test in the aggressive chloride environment. The exposure time of the specimens was five hours. To show the effects of corrosion the layer of aluminum(III) oxide and copper(II) oxide was removed from the surface of the samples. For this purpose dilute nitric acid was used and the exposure time was about three minutes. The surface of the $\mathrm{Al} / \mathrm{Cu}$ alloy that was not heat treated was destroyed in an acid chloride environment as a result of electrochemical corrosion (Figure 11a). 
Figure $11 \mathrm{~b}$ shows the surface of the $\mathrm{Al} / \mathrm{Cu}$ alloy (which was previously subjected to thermal treatment at $400{ }^{\circ} \mathrm{C}$ ) after exposure in the corrosive environment. It is worth noting slight damage of the surface of the Al-Cu coating as a result of corrosion occurred. Therefore, the $\left(\mathrm{Al}_{2} \mathrm{O}_{3}\right)_{\mathrm{ads}}$ and $(\mathrm{CuO})_{\text {ads }}$ layer was tight and effectively protected the metal surface from contact with the electrolyte.

After heat treatment of the $\mathrm{Al} / \mathrm{Cu}$ alloy at an elevated temperature, i.e., $600{ }^{\circ} \mathrm{C}$, the structure of $\left(\mathrm{Al}_{2} \mathrm{O}_{3}\right)_{\text {ads }}$ and $(\mathrm{CuO})_{\text {ads }}$ oxides was destroyed. Therefore, under the conditions of the experiment of the $\mathrm{Al} / \mathrm{Cu}$ surface was damaged (Figure 11c).
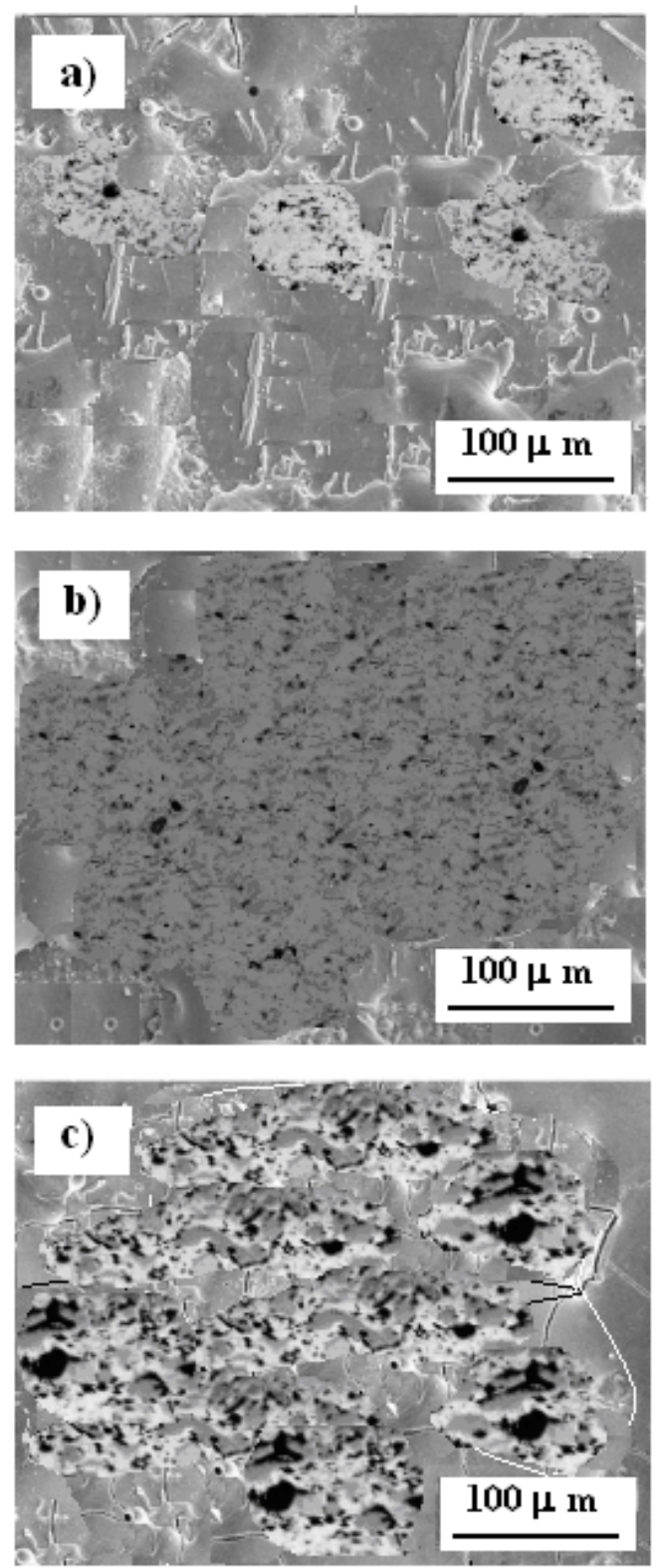

Figure 11. Photograph images of the $\mathrm{Al} / \mathrm{Cu}$ surface: (a) before and after heat treatment at: (b) $400{ }^{\circ} \mathrm{C}$ or (c) $600{ }^{\circ} \mathrm{C}$ in air atmosphere and after the corrosion test in $1.2 \mathrm{M} \mathrm{Cl}^{-}, \mathrm{pH} 1.5$. Exposure time was five hours.

The numerous pits and deep cavities were appeared on the alloy surface as a result of electrochemical corrosion. 


\section{Conclusions}

1. The aluminum-copper coating on the aluminum substrate was produced by the electrical discharge alloying method.

2. The surface of the $\mathrm{Al} / \mathrm{Cu}$ alloy contains an average of $31 \% \mathrm{Al}$ and $68 \% \mathrm{Cu}$ and traces of other elements.

3. The mechanical properties of the Al-Cu coating after heat treatment in the air atmosphere significantly increased or decreased at $400{ }^{\circ} \mathrm{C}$ or $600{ }^{\circ} \mathrm{C}$, respectively.

4. After heat treatment at $400{ }^{\circ} \mathrm{C}$ the oxide layer, i.e., $\left(\mathrm{Al}_{2} \mathrm{O}_{3}\right)$ ads and $(\mathrm{CuO})_{\text {ads }}$ protected of the $\mathrm{Al} / \mathrm{Cu}$ alloy surface against corrosion in the aggressive chloride environment.

5. However, after heat treatment at an elevated temperature i.e., $600{ }^{\circ} \mathrm{C}$, the oxide coating structure was destroyed. Therefore, the mechanical properties of the $\mathrm{Al} / \mathrm{Cu}$ alloy decreased and its surface had undergone deep electrochemical corrosion.

Author Contributions: Conceptualization, M.S. and S.S.; formal analysis, M.S. and K.S.-S.; investigation, K.S.-S. and P.M.; methodology, M.S.; writing-original draft, M.S. and K.S.-S.; writing-review and editing, M.S. All authors have read and agreed to the published version of the manuscript.

Funding: These studies were not financed from outside.

Acknowledgments: The authors thank Dominica Kaminska for cooperation and participation in experiments.

Conflicts of Interest: The authors declare no conflict of interest.

\section{References}

1. Spadło, S.; Młynarczyk, P. Selected properties of the micro electrical discharge alloying process using copper electrode on aluminum. Transp. Res. Procedia 2019, 40, 96-101. [CrossRef]

2. Scendo, M.; Radek, N.; Trela, J. Influence of laser treatment on the corrosive resistance of WC-Cu coating produced by electrospark deposition. Int. J. Electrochem. Sci. 2013, 8, 9264-9277.

3. Scendo, M.; Radek, N.; Trela, J. The influence of electrospark and laser treatment upon corrosive resistance of carbon steel. Adv. Mater. Res. 2014, 874, 107-112. [CrossRef]

4. Scendo, M.; Trela, J.; Radek, N. Influence of laser power on the corrosive resistance of WC-Cu coating. Surf. Coat. Technol. 2014, 259, 401-407. [CrossRef]

5. Spadło, S.; Kozak, J.; Młynarczyk, P. Mathematical modelling of the electrical discharge mechanical alloying process. Procedia CIRP 2013, 6, 422-426. [CrossRef]

6. Fathy, A.; El-Kady, O.; Mohammed, M.M. Effect of iron addition on microstructure, mechanical and magnetic properties of Al-matrix composite produced by powder metallurgy route. Trans. Nonferrous Met. Soc. China 2015, 25, 46-53. [CrossRef]

7. Selvakumar, S.; Dinaharan, I.; Palanivel, R.; Babu, B.G. Characterization of molybdenum particles reinforced Al6082 aluminum matrix composites with improved ductility produced using friction stir processing. Mater. Charact. 2017, 125, 13-22. [CrossRef]

8. Park, K.; Park, J.; Kwon, H. Effect of intermetallic compound on the Al-Mg composite materials fabricated by mechanical ball milling and spark plasma sintering. J. Alloys Compd. 2018, 66, 311-318. [CrossRef]

9. Park, K.; Kim, D.; Cho, S.; Kwon, H. Behavior of intermetallic compounds of Al-Ti composite manufactured by spark plasma sintering. Materials 2019, 12, 331. [CrossRef]

10. Moghadam, A.D.; Omrani, E.; Menezes, P.L.; Rohatigi, P.K. Mechanical and tribological properties of self-lubricating metal matrix nanocompssities reinforced by carbon nanotubes (CNTs) and graphene-A review. Compos. Part. B Eng. 2015, 77, 402-420. [CrossRef]

11. Eizadjou, M.; Kazemitalachi, A.; Daneshmanesh, H.; Shahabi, H.S.; Janghorban, K. Investigation of structure and mechanical properties of multi-layered $\mathrm{Al} / \mathrm{Cu}$ composite produced by accumulative roll bonding (ARB) process. Compos. Sci. Technol. 2008, 68, 2003-2009. [CrossRef]

12. Xu, H.; Liu, C.; Siberschmidt, V.V.; Pramana, S.; White, T.; Chen, Z.; Acoff, V. Behavior of aluminum oxide, intermetallics and voids in Cu-Al wire bonds. Acta Mater. 2011, 59, 5661-5673. [CrossRef] 
13. Kim, K.; Kim, D.; Park, K.; Cho, M.; Cho, S.; Kwon, H. Effect of intermetallic compounds on the thermal and mechanical properties of Al-Cu composite materials fabricated by spark plasma sintering. Materials 2019, 12, 1546. [CrossRef] [PubMed]

14. Chen, G.; Lu, L.P.; Ren, C.Z.; Ge, X. Temperature dependent negative to positive strain rate sensitivity and compression behavior for 2024-T351 aluminum alloy. J. Alloys Compd. 2018, 765, 569-585. [CrossRef]

15. Liu, L.; Wu, Y.X.; Gong, H.; Dong, F.; Ahmad, A.S. Modified kinetic model for describing continuous dynamic recrystallization behavior of Al2219 alloy during hot deformation process. J. Alloys Compd. 2020, 817, 153301. [CrossRef]

16. Lin, Y.C.; Wu, Q.; He, D.G.; Zhu, X.H.; Liu, D.Y.; Li, X.H. Effects of solution time and cooling rate on microstructures and mechanical properties of $2219 \mathrm{Al}$ alloy for a larger spun thin-Wall ellipsoidal head. J. Mater. Res. Technol. 2020, 9, 3566-3577. [CrossRef]

17. Lin, Y.C.; Dong, W.-Y.; Zhu, X.-H.; Wu, Q.; He, Y.-J. Deformation behavior and precipitation features in a stretched Al-Cu alloy at intermediate temperatures. Materials 2020, 13, 2495. [CrossRef]

18. Sheng, L.Y.; Yang, F.; Xi, T.F.; Lai, C.; Ye, H.Q. Influence of heat treatment on interface of Cu/Al bimetal composite fabricated by cold rolling. Compos. Pt. B Eng. 2011, 42, 1468-1473. [CrossRef]

19. Lee, S.; Lee, M.G.; Lee, S.P.; Lee, G.A.; Kim, Y.B.; Lee, J.S.; Bae, D.S. Effect of bonding interface on delamination behavior of drawn Cu/Al bar clad material. Trans. Nonferrous Met. Soc. China 2012, 22, 5645-5649. [CrossRef]

20. Honarpisheh, M.; Asemabadi, M.; Sedighi, M. Investigation of annealing treatment on the interfacial properties of explosive-welded Al/Cu/Al multilayer. Mater. Des. 2012, 37, 122-127. [CrossRef]

21. Li, X.B.; Zu, G.Y.; Ding, M.M.; Mu, Y.L.; Wang, P. Interfacial microstructure and mechanical properties of $\mathrm{Cu} / \mathrm{Al}$ clad sheet fabricated by asymmetrical roll bonding and annealing. Mater. Sci. Eng. A 2011, 529, 485-491. [CrossRef]

22. Li, X.B.; Zu, G.Y.; Wang, P. Microstructural development and its effects on mechanical properties of $\mathrm{Al} / \mathrm{Cu}$ laminated composite. Trans. Nonferrous Met. Soc. China 2015, 25, 36-45. [CrossRef]

23. Abbasi, M.; Taheri, A.K.; Salehi, M.T. Growth rate of intermetallic compounds in Al/Cu bimetal produced by cold roll welding process. J. Alloys Compd. 2001, 319, 233-241. [CrossRef]

24. Chen, C.Y.; Hwang, W.S. Effect of annealing on the interfacial structure of aluminum-Copper joints. Mater. Trans. 2007, 48, 1938-1947. [CrossRef]

25. Scendo, M.; Staszewska-Samson, K. Effect of surface modification on corrosion resistance of uncoated and DLC coated stainless steel surface. J. Mater. Eng. Perform. 2017, 26, 3946-3953. [CrossRef]

26. Scendo, M.; Trela, J.; Antoszewski, B.; Kargul, T. Corrosion resistance of the joint of stainless steels in aggressive solution. Innov. Corros. Mater. Sci. 2014, 4, 118-126. [CrossRef]

27. Pretorius, R.; Vredenberg, A.M.; Saris, F.W.; de Reus, R. Prediction of phase formation sequence and phase stability in binary metal-aluminum thin-film systems using the effective heat formation rule. J. Appl. Phys. 1991, 70, 3636-3646. [CrossRef]

28. Pretorius, R.; Theron, C.C.; Vantomme, A.; Mayer, J.W. Compound phase in thin film structures. Crit. Rev. Solid State Mater. Sci. 1999, 24, 1-62. [CrossRef]

29. Scendo, M.; Staszewska-Samson, K. Effect of temperature on anti-corrosive properties of diamond-like carbon coating on S355 steel. Materials 2019, 12, 1659. [CrossRef]

30. Staszewska, K.; Scendo, M. Mechanism and kinetics oxidation of Inconel 617 and 625 alloys. Tech. Issues 2016, 1, 82-89.

(C) 2020 by the authors. Licensee MDPI, Basel, Switzerland. This article is an open access article distributed under the terms and conditions of the Creative Commons Attribution (CC BY) license (http://creativecommons.org/licenses/by/4.0/). 